\title{
NORM AS A LINGUISTIC CONCEPT: \\ DYNAMICS AND CODIFICATION
}

\section{НОРМА ЯК ЛІНГВІСТИЧНЕ ПОНЯТТЯ: ДИНАМІКА ТА КОДИФІКАЦІЯ}

\author{
Yuliia Pozdran ${ }^{1}$ \\ Iryna Zozulya ${ }^{2}$
}

DOI: https://doi.org/10.30525/978-9934-588-15-0-146

\begin{abstract}
This academic research is devoted to the problem of understanding the norm as a sociolinguistic category. The relevance of a conducted study is linked to the fact that there is no single approach in modern linguistics to the normativity interpretation in a general context and some specific norms of literary language particularly. In the course of our research changes and specification of the "norm" concept have been identified in scientific definitions that occurred at the 20th and the beginning of the 21st centuries. Moreover, new aspects of understanding the norm have been determinated. It is found that at the beginning of the 20th century linguists pointed the systemic nature of the norm and interpreted it as a complex well-ordered structure, the top of which is occupied by literary language. This aspect has remained constant in a sense of the "norm" concept to this day. However, modern research workers recognize the dual nature of the norm as a systemic and social phenomenon all the while. They interpret it as the most everlast linguistic fact, selected in the process of public communication, which corresponds to the language system and has got public approval and recognition. It is proved that the recognition of a language norm results in its codification in authoritative publications, particularly dictionaries. It was found out that the development of the Ukrainian literary language was significantly influenced by the codification of the 20-30's years of the 20th century. After all, it was then when principles of scientific studies of a language vocabulary were determined. Researchers
\end{abstract}

\footnotetext{
${ }^{1}$ Candidate of Philology, Senior Lecturer, Department of Linguistics,

Vinnytsia National Technical University, Ukraine

${ }^{2}$ Candidate of Pedagogical Sciences, Associate Professor, Department of Linguistics,

Vinnytsia National Technical University, Ukraine
}

(C) Yuliia Pozdran, Iryna Zozulya 
controverted spontaneous norms and focused on systemic principles of normalization of the Ukrainian literary language, which has not lost its relevance to this day. It is confirmed that the most reliable fixers of changes in a language lexical and semantic system and codifiers of literary language norms are standard language lexicographic works. They reflect the level of literary norms development and the state of social linguistic consciousness of an ethnic group in one or another period. Linguistic normative dictionaries help us foster a person culture and are means of a purposeful and scientifically based language policy. Users of linguistic dictionaries enhance their own language culture and develop a linguistic taste and a sense of word. The study makes the differentiation between descriptive and prescriptive norms by the following criteria: an attitude to a language (appraisive/non-evaluative); description / selection of a language material; presence / absence of recommendations for use of a language material. A descriptive norm is considered to be a system of multilevel units that actually function in a language. A prescriptive norm is mainly a codified system of language units that is regulated by means of instructions and recommendations.

\section{1. Вступ}

Праці з ділянки кодифікації літературної мови завжди мають підвищений попит у суспільстві, особливо сьогодні, коли з одного боку українське в «тренді», а 3 іншого - доводиться знову відстоювати право української мови на повноцінне функціонування в усіх сферах суспільної комунікації, такі дослідження є особливо актуальними, адже засвідчують високий потенціал української мови у формуванні власними засобами «свого» мовного простору.

Поняття «мовна норма» $€$ засадничим для формування корпусу літературної мови, адже лише нормативний опис літературної мови відкриває перспективу формулювання положень правопису, перенесення теоретичних узагальнень мови у практику іï викладання в навчальних закладах і поширення в різних комунікативних ситуаціях.

Аналіз наукових досліджень і публікацій засвідчив, що в різні періоди розвитку літературної мови мовознавці приділили увагу дослідженню мовної норми, однак природа й обсяг поняття «норма» потребують подальшого детального вивчення з урахуванням розвитку лінгвістичної теорії та практики. 
Актуальність проведеного дослідження зумовлена тим, що в сучасній лінгвістиці не існує єдиного підходу до трактування нормативності взагалі, й окремих конкретних норм літературної мови зокрема. Сучасне визначення терміна «норма» в науковій практиці неоднозначне. Розбіжності в його трактуванні зумовлені різними підходами до проблеми нормативності. Це стосується загальної теорії мови, культури мови, а також практичних міркувань мовної культури [41, с. 34]. Тому в поняття «норма» часто вкладають різний зміст.

Метою дослідження є простеження змін та уточнень у наукових дефініціях поняття «норма», що відбувалися протягом XX - початку $\mathrm{XXI}$ ст., виокремлення нових аспектів розуміння норми.

\section{2. Динаміка поняття мовної норми в діахронії}

Підвалини сучасного розуміння процесів мовного нормування закладено у 30-ті pp. XX ст. представниками Празької лінгвістичної школи В. Матезіусом, Б. Гавранком, Й. Вахком, положення яких і сьогодні не втратили своєї актуальності. Зокрема, Б. Гавранек 1936 р. ставив питання, чи може бути норма, нормування літературної мови й мовна культура предметом лінгвістичних досліджень, і довів, що вивчення мовної норми належить до наукових лінгвістичних завдань.

Празькі мовознавці наголосили на свідомому «перетворенні мови як простого засобу, простого представника об'єктивного світу, в самостійний об'єкт наших роздумів, наших емоцій» [54, p. 2]. У їхніх розвідках, як доводить О.С. Клименко, поняття реальної норми звільняється від конотацій оцінки і припису та відокремлюється від кодифікації норм [15, с. 155]. Таке розуміння норми стало значним кроком уперед і сприяло переходу від фактуального й нормативного способів дослідження мови до порівняльно-історичного методу. Теза вчених Празької лінгвістичної школи про реальність існування мовної норми, за результатами спостереження О.С. Клименка, дала змогу вивчати реальну картину буття мови, не спотворюючи іiі упередженим

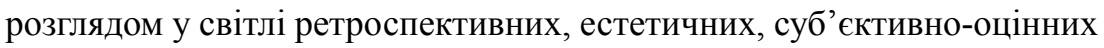
категорій [15, с. 155].

Спостереження за зміненнями норми в часі й у їі функціональній варіативності уможливило з'ясування їі діалектичної сутності і власне мовної природи [41, с. 34]. У цілому заслугою представників Празь- 
кої лінгвістичної школи є вивчення норми як «лінгвосоціологічного i конкретно-історичного феномена» [33] й визначення ії як сукупності структурних засобів, які регулярно використовує мовний колектив.

Значно вплинула на формування сучасного розуміння поняття «норма» теорія Л. Єльмслева та Е. Косеріу. Для Л. Сльмслева мовна норма - фікція, штучна абстракція: нею, переконаний дослідник, замінюють факти узусу, а це призводить до непотрібних ускладнень; із лінгвістики категорію норми можна вилучити, резюмує автор [8, с. 173]. Однак Г. Нельсон не погоджується з такою думкою: норму не можна вилучати з лінгвістики, оскільки мета нормотворчої діяльності полягає в розробленні й поширенні правил, яких мовці мають дотримуватися в мовленні [56, p. 463].

У 50-ті pp. ХX ст. С.І. Ожегов сформулював відому дефініцію норми, на якій грунтувалися наступні наукові формулювання: «Норма це сукупність найбільш придатних («правильних», «найкращих») для обслуговування суспільства засобів мови, які складаються як результат добору мовних елементів .. $з$ наявних, утворюваних знову чи добутих із пасивного запасу минулого в процесі соціальної, в широкому розумінні, оцінки цих елементів» [28, с. 15].

Протягом 50-70-х pp. XX ст. у межах соціолінгвістики вперше здійснено спробу комплексного підходу до мовних проблем: починаючи від регулювання функціонального розподілу мов у складних мовних ситуаціях (мовної політики) до питань літературних стандартів (правописної та термінологічної кодифікації тощо) [52, с. 11]. Однак основну увагу дослідники зосереджують не на мовнонормативних завданнях, а на розробленні відповідних методів і прийомів (праці Е. Хаугена, Ч. Фергюсона, Дж. Фішмана та ін.).

Поняття «мовна норма» зазнає змін та уточнень у 80-х - середині 90-х pр. ХХ ст. у працях представників Московсько-Тартуської семіотичної школи Ю.М. Лотмана, Б.А. Успенського, В.М. Живова, які досліджували історію літературної норми з детальним урахуванням політичних та ідеологічних позицій учасників процесів мовного нормування, а також характеристик соціального та культурного процесів у певних історичних обставинах. Цей підхід сформувався в руслі загальної переорієнтації лінгвістики, яку тепер найчастіше позначають як перехід від системоцентризму до антропоцентризму [52, с. 12]. 
Антропоцентризм у лінгвістиці передбачає послідовне врахування «людського фактора» або «людської перспективи» у процесах мовного функціонування.

Вагомий внесок у дослідження поняття «норма» зробив Л.П. Крисін. Досліджуючи сучасну літературну норму, він відзначив, що в лінгвістиці термін «норма» функціонує у двох значеннях - широкому й вузькому. Так, у широкому сенсі норма - це традиційно і стихійно сформовані засоби мовлення, які відрізняють даний мовний ідіом від інших мовних ідіомів. У вузькому ж розумінні нормою є результат цілеспрямованої кодифікації мови [20, с. 233]. Таке бачення норми нерозривно пов'язане 3 поняттям літературної мови, яку інакше називають нормованою, або кодифікованою. Сам же дослідник мовною нормою вважає «сукупність найбільш стійких мовних засобів та правил їх вживання, які є традиційними та прийнятними в певному суспільстві в певну епоху» [20, с. 233].

Л.А. Вербицька трактує норму як усвідомлення певних засобів мовного вираження правильними, зразковими та припис їхнього використання (кодифікація) [2, с. 12]. Тобто, на думку дослідниці, літературна мова не так утілює в собі ідеальні норми, як відображає загальномовну тенденцію до їх створення з точки зору оптимальності мовного вираження.

В українському мовознавстві питання норми було актуалізоване ще на початку 20 -х років XX ст. - часу особливого розквіту українознавства. Це був період, за словами Т.П. Мельник, «усталення та наукової легітимації норм літературної мови» [25, с. 7]. На заваді виробленню мовних стандартів у цей період стала різноговіркова основа літературних праць, що були написані впродовж століття. Зважаючи на цю потужну традицію літературної мови, було б нерозумно, на думку Ю.В. Шевельова, відкидати ті ії елементи, які вже прищепилися, навіть якщо вони не мають підгрунтя в жодній київській чи полтавській говірці [48, с. 13]. Для того, щоб обрати й закріпити в літературній мові найдоцільніший варіант мовознавці мали врахувати не лише традиційне (минуле), а й простежити тенденції розвитку мови в майбутньому, «знайти балянс між вірністю традиції й розумінням лінії розвитку» [48, с. 13].

М.Ф. Сулима стверджував, що літературна норма - це «конче потрібна річ», оскільки вона «становить найпершу та найхарактернішу ознаку літературної мови» [42, с. 132]. С.П. Шевченко зазначає, 
що О.Н. Синявський та М.Ф. Сулима, критично підійшовши до надбань представників етнографічної школи в українському мовознавстві 20-х pp. XX ст., переглянули їх у контексті традиції та перспектив розвитку мови [49, с. 50]. Це стало можливим завдяки ретельному вивченню особливостей мови провідних письменників минулого й сучасності.

М.А. Жовтобрюх наголошував на важливому соціальному значенні мовної норми, адже «тільки єдиний правопис і стала вимова, обов'язкові для всіх правила відмінювання слів і синтаксичних зв'язків між словами, однакове розуміння змісту вживаних слів, єдиний наголос у словах по-справжньому створюють ті якості літературної мови, що потрібні їй як засобу спілкування між людьми, об'єднаними у великий колектив» $[12$, с. 4]. Погоджуючись із цим, Є.Д. Чак переконувала, що «для визначення нормативності мови треба дослідити не тільки правильність лексем, а й доречність вживання їх» [46, с. 4-5]. Це, на думку дослідниці, одне з найважчих і найважливіших завдань лінгвістики.

А.П. Коваль стверджувала, що норми літературної мови - це історично змінне явище. Середовищем, у якому вони творяться, є жива мовна практика, постійне спілкування людей у різних сферах діяльності. На думку дослідниці, причиною змінення норм найчастіше є змінення в житті суспільства, а також вплив внутрішніх законів мови [16, с. 3$]$.

Попри певні розбіжності в поглядах як мовознавців, так і лінгвістичних шкіл (української, російської, чеської, польської та ін.), в усіх дефініціях норми наголошено на іiі суспільному характері. Працівники відділу стилістики та культури мови Інституту української мови НАН України під керівництвом С.Я. Срмоленко сьогодні активно працюють над вивченням багатоплановості явища літературної норми, установленням критеріїв літературної норми та з'ясуванням відмінностей у змісті понять «мовна норма» й «літературна норма». Зокрема, С.Я. Єрмоленко тлумачить норму як «сукупність мовних засобів, що відповідають системі мови й сприймаються іiі носіями як зразок суспільного спілкування у певний період розвитку мови і суспільства» [45, с. 438], як певний «конструкт, який витворюється в свідомості людей, належних до однієї комунікативної спільності» [11, с. 66]. Це свідчить про розуміння подвійної природи норми - як явища системного й суспільного, на що свого часу вказував і М.М. Пилинський [31, с. 94]. 
С.П. Бибик відзначає, що «саме поняття норми передбачає як співвідношення «правильне - неправильне», властиве літературній мові, так і стилістичну диференціацію одиниць мови, закріплених чи то за усною / писемною формою спілкування, чи то за певним функціональним стилем мови, чи то за конкретною стилістичною ситуацією» [1, с. 59]. Г.М. Сюта значну увагу приділяє з'ясуванню впливу індивідуальної мовотворчої практики письменників на становлення літературної мови й літературної норми, який визначає як «структурно-розширювальний або огранювальний, спрямований на удосконалення» [43, с. 54]. Дослідниця вважає, що в сучасній українській лінгвостилістиці норма «активна метамовна одиниця досліджень, пов'язаних із визначенням дистрибутивних рис слововживання, образотворення, текстотворення в мові поезії та прози певних літературних епох чи течій, соціально й культурно значущих періодів, жанрових спрямувань тощо» [43, с. 56].

O.О. Селіванова визначає мовну норму як «обрані у процесі комунікативної взаємодії з числа варіантів мовної реалізації, уніфіковані, свідомо фіксовані й найбільш поширені традиційні зразки (стандарти) репрезентації системи мови (засоби мови і правила їхнього вживання)» [34, с. 346].

Найповніше, на нашу думку, літературну норму трактує M.М. Пилинський: «Норма літературної мови - це реальний, історично зумовлений і порівняно стабільний мовний факт, що відповідає системі й нормі мови і становить єдину можливість або найкращий для даного конкретного випадку варіант, відібраний суспільством на певному етапі його розвитку із співвідносних фактів загальнонародної (національної) мови в процесі спілкування» [31, с. 94]. На думку М.М. Пилинського, у мовній нормі суспільний характер проявляється ще сильніше, ніж суспільний характер мови взагалі. Норма є об'єднувальним і зміцнювальним елементом літературної мови на всіх етапах іiі розвитку [18, с. 47]. Вироблення норм сприяє впорядкуванню мовної системи та консолідації національного простору.

Детальну історію розвитку поняття норми подає Н.М. Семенюк [37], уточнюючи тріаду Е. Косеріу «система - норма - мовлення» так: «структура - норма - узус». Розрізнення норми й узусу міститься ще в перших працях Б. Гавранка, згодом (хоча й у трохи різних формулюваннях) у студіях Н.М. Семенюк [37], С.В. Семчинського [38], О.О. Лаптєвої [21] та інших учених. Мовознавці по-різному тлумачать термін 
«узус». В одних випадках узус ототожнюють з індивідуальним мовленням, а в інших трактують як постійне пристосування мовної системи до потреб носіїв мови. До узусу зараховують мовні норми, які виходять за межі літературної мови, а також окремі нормативні підсистеми у складі літературної мови. Д.І. Ганич та І.С. Олійник у «Словнику лінгвістичних термінів» дають таку дефініцію: «Узус (лат. usus - звичай, правило) прийняте носіями певної мови вживання слів, словоформ, синтаксичних конструкцій тощо» [4, с. 316]. Російський «Лінгвістичний енциклопедичний словник» трактує узус як колективну мовну практику, застерігаючи, що індивідуальні утворення не є узуальними одиницями мови [22]. Отже, узус мови неоднорідний, оскільки залежить від територіального чинника й суспільного становища мовців.

Окреслюючи поняття норми літературної мови, мовознавці Ю.А. Бєльчиков, С.П. Бибик, К.С. Горбачевич, С.Я. Єрмоленко, Г.П. Мацюк, О.Г. Муромцева, С.І. Ожегов, М.М. Пилинський, В.М. Русанівський, Л.В. Струганець, Г.М. Сюта, Н.В. Хруцька, Г.М. Яворська та ін. відзначають одну з найважливіших їі рис - історичний характер. Уже у визначенні норми підкреслено ії зв'язок із певним синхронним зрізом мови [26, с. 18]. Зміна норм літературної мови тісно пов'язана зі зміною епох, адже діяльність народу - носія мови - також розвивається. М.Д. Гладкий зазначав: «Нормальний хід розвитку кожної мови такий, що старі, давно вживані слова, звороти й конструкції відмирають не враз, а живуть часто сотні літ, помалу гублять своє первісне значення, відмінюють його й стають привичними шаблонами, тими відомими 3 дитячих літ образами, що полегшують нам процес сприймання нового й заощаджують тим психічну енергію» [5, с. 70]. Вимога стабільності, як доводить Л.В. Струганець, узгоджується 3 природною мінливістю, яка властива мові як соціальному явищу історичного характеру [41, с. 37]. Цей процес мовознавці Празької лінгвістичної школи назвали «гнучкою стабільністю» [23, с. 381], а українські лінгвісти - С.Я. Срмоленко [9, с. 227], О.О. Тараненко [44, с. 55], Л.В. Струганець [40, с. 12] та ін., - динамікою мовної норми. Як слушно зазначає Є.А. Карпіловська, мовна норма «змінюється разом із мовою відповідно до нових потреб суспільної практики» [14, с. 43].

У зв'язку з тим, що динамічна теорія норми пропонує враховувати й об'єктивні тенденцій розвитку мови, які не залежать від волі носіїв 
мови, і цінність успадкованих літературних традицій, вона стала загальнонауково визнаною порівняно недавно. Тривалий час серед мовознавців переважало догматичне уявлення про штучний характер літературних мов і вдавану непорушність їхніх норм [6, с. 78]. Це часто призводило до ототожнення понять «розвиток мови» і «псування мови». Будь-яке мовне новоутворення вважали того часу спотворенням мови, засуджували й забороняли. Однак погоджуємося з С.А. Карпіловською в тому, що мова є стійкою й рухливою, і норма «не повинна ставати на заваді іiі розвитку, має змінюватися з часом, відповідати на нові пізнавальні й комунікативні потреби спільноти і задовольняти нові іiї смаки й уподобання» [14, с. 50].

\section{3. Кодифікація мовної норми}

Сьогодні мовознавці погоджуються з тим, що прийняті норми через певні проміжки часу потребують перегляду й переоцінки. Ретроспективною, найбільш експліцитною й об'єктивною формою суспільного прийняття мовних норм, на думку Т.А. Коць, є кодифікація [18, с. 48]. Саме кодифікація відбиває ті явища, які усталилися у процесі мовної практики [40, с. 22; 45, с. 269]. Термін «кодифікація» запропонували мовознавці Празької лінгвістичної школи у 30-х рp. ХХ ст. Кодифікацією також називають систему обов'язкових правил для вживання літературної мови, усвідомлених та прийнятих у конкретний період усім мовним колективом [49, с. 49].

За визначенням Г.П. Мацюк, кодифікація - це «процес, сутність якого розкривається внаслідок мовознавчого пізнання норм літературної мови і практики їхньої реалізації, який у конкретні періоди розвитку літературної мови має теоретичний і практичний вияви й експлікується на описовому, регулятивному етапах та етапі реалізації» [24, с. 41]. С.Я. Єрмоленко також підкреслює, що кодифікація лексичної норми в нормативному словнику «відбиває характер сучасної мовної практики і не може охоплювати лексикон певних історичних зрізів української літературної мови» [10, с. 13]. Таким чином, кодифікація $\epsilon$ результатом наукового пізнання закономірностей вияву норми на певному етапі розвитку мови.

С.П. Шевченко слушно зауважує, що норма й кодифікація не тотожні поняття: норма динамічна, змінювана категорія, а кодифіка- 
ція - статична за своїм характером [49, с. 51]. Вона зберігає та фіксує норму в певний період розвитку мови, сприяє забезпеченню більшої стійкості норм та запобігає напівстихійним і начебто неконтрольованим нею змінам [41, с. 41].

На відмінності норми й кодифікації акцентують і польські мовознавці, які трактують норму не як сукупність правил уживання мовних одиниць (історико-соціологічний аспект), а як один із рівнів внутрішньої структури мови (власне лінгвістичний аспект). Кодифікацію польські лінгвісти розуміють як зовнішній щодо мови факт [19, с. 162]. Мовознавець А. Марковський образно називає кодифікацію «фотографією» норми, зробленою на основі мовних текстів [57]. А.М. Кравчук, продовжуючи образний ряд, альбомами для таких фотокарток вважає граматики та словники, які фіксують норму [19, с. 162].

Як стверджує Л.В. Струганець, мовна норма і ії кодифікація у граматиках і словниках перебувають у полярному взаємовідношенні, оскільки кодифікація норми залежить від реальної норми (що повніші знання про літературну норму, то точніша й кодифікація), і навпаки кодифікована норма також впливає на реальну норму, поступово змінює іï й часто досить ефективно [40]. Кодифікація здатна стабілізувати й регулювати функціонування та розвиток літературної норми. А. Єдлічка вважає, що метою кодифікації є розкриття та фіксація синхронної динаміки сучасної літературної норми й тим самим створення умов, за яких кодифікація не була б гальмом природного й суспільно зумовленого розвитку літературної норми [27, с. 38-134]. Я. Фіндра 3 цього приводу слушно зауважує, що кодифікація - не корсет, який мав би умертвити норму [53, p. 83]. Тому статичний характер кодифікації не перешкоджає ій регулювати вживання мовних засобів вираження i зумовлювати зміни в узусі та нормі.

Суперечність між динамікою норми і статичністю кодифікації намагався подолати М. Докуліл, вимагаючи, щоб кодифікація поряд зі своєю статичністю мала й певну перспективну глибину, тобто в момент свого виникнення вона має кодифікувати певні явища з урахуванням майбутнього розвитку [27]. Окрім того, кодифікація має бути адекватною сучасній для неї нормі. Це є основним принципом, що лежить в основі наукової кодифікації літературної мови. І тому небезпечнішою $€$ не передчасна кодифікація того, що ще не стало нормою, а відмова від 
визнання прав літературної норми за тими явищами, які фактично вже стали нормою, небезпечна орієнтація на стару норму [13, с. 28-30, 39].

Твердження М.М. Пилинського щодо непослідовності розрізнення норми та кодифікації в українській науковій літературі не втратило своєї актуальності й сьогодні. На його думку, недостатньо вивченим є взаємовідношення цих двох явищ, зокрема вплив кодифікації на норму, умовно кажучи, сила, темпи й межі цього впливу [31, с. 67]. Погоджуємося 3 Т.П. Мельник, яка вважає, що нормування - це зведення до єдиної системи приписів, які регулюють використання мовних засобів на етапі становлення чи зміни мовних норм, а кодифікація - закріплення цих приписів у нормативних працях, що мають суспільне значення [25, с. 7]. Такими нормативними працями $\epsilon$, насамперед, словники. Слушною $є$ думка Л.С. Паламарчука про те, що «словники - і загальномовні, і спеціальні різної спрямованості, - опрацьовані на засадах сучасної лексикографічної науки, $є$ тим головним інструментом, що зміцнює й закріплює вироблену мовну норму, забезпечує необхідну для кожної мови кодифікацію лексичних засобів усіх категорій» [29, с. 170].

В основі загальномовного нормативного словника лежить розуміння норми як способу мовного вираження, який, по-перше, відображає об'єктивні закономірності мовної системи, а по-друге, отримує суспільне схвалення, що підтверджує слововживання авторитетних письменників [6, с. 78]. Ураховуючи це, завдання нормативного словника полягає не тільки в максимально точному й повному тлумаченні значень і відтінків значень усіх слів, уведених до реєстру, але й в оцінці їхніх стилістичних, граматичних та акцентологічних особливостей, а в перекладному словнику - вдалості підібраних перекладних еквівалентів [32, с. 41].

П.Й. Горецький стверджував, що «словник, фіксуючи певні слова й ілюструючи їх прикладами літературного вжитку, тим самим у великій мірі стає словником нормативним» [7, с. 11]. Г.М. Яворська зауважує, що нормативний словник «лише кодифікує наявну літературну норму, що усталилася в мовному вжитку, а не робить нормативним те чи інше конкретне слововживання» [52, с. 13]. Однак вважаємо, що це не завжди так, адже ввівши до реєстру словника діалектизм, вульгаризм, просторіччя тощо й не поставивши при ньому відповідної ремарки, слово буде сприйматися користувачами словника як нормативне. 
Укладання словників, що є кодифікаторами мовної норми, - це важка й відповідальна праця, оскільки нормативність - явище відносне: літературна мова $є$ динамічною системою, якій властиві механізми збагачення, поповнення, розвитку [47, с. 168]. Тому укладачі нормативного словника мають розробити чітку систему принципів, що будуть регулювати можливість уведення того чи того слова до реєстру. На цьому свого часу наголошував також Л.С. Паламарчук, вважаючи, що нормативний словник має бути укладений із «дотриманням наукових засад і виробленої для нього наукової концепції» [29, с. 16].

Нормативний словник, зберігаючи культурні мовні традиції, має водночас звільнитися від надуманих догм, які гальмують розвиток мови. На думку К.С. Горбачевича, він має проявляти розумну стриманість, виходити не зі «смакового» пуризму, а зі знання закономірностей розвитку мови, зі спостережень за матеріалами сучасного слововживання [6, с. 86].

Л.В. Струганець стверджує, що словник як кодифікаційна праця певною мірою «запрограмований» на неадекватне відображення реальних мовних норм. Це зумовлено комплексом зовнішніх та внутрішніх недоліків, властивих кодифікації. До зовнішніх недоліків дослідниця відносить типовий для багатьох нормативних описів ригоризм, відсутність вказівок на варіанти й на сфери функціонування варіантів у межах літературної мови, невідповідність кодифікації сучасній нормі, орієнтацію на стару норму, а до внутрішніх - сам факт існування кодифікації [40]. На думку Л.В. Струганець, кодифікаційні праці, насамперед словники, стають зразком для наступних нормативних праць i таким чином на багато років закріплюють функціонування вже неактуальної старої мовної норми. Польський лексикограф Я. Карлович писав, що словник має бути поза будь-якими граматичними чи пуристичними теоріями й об'єктивно представляти весь інвентар мови, на основі якого (але вже поза ним) мовознавці можуть давати свої оцінки щодо мови [57].

Подеколи термін «нормативний словник» ототожнюють із терміном «словник академічного типу» або «академічний словник». Зокрема, Л.В. Щерба під академічним словником розумів нормативний словник, оскільки, якщо б справа була у формальній назві чи виданні, то будь-який словник, виданий в Академії, вважався б академічним [51]. 
Д.М. Шмельов нормативним вважає словник, який «достатньо послідовно обмежує те, що реально існує в літературній мові певної епохи, й те, що лише спорадично проникає у неї (з діалектів, жаргонів, мови попередніх епох, відомої нам через книги та ін.) як самим реєстром, так і за допомогою відповідних ремарок» [50, с. 45]. Однак найповніше визначення академічного словника, на нашу думку, дає В.Ф. Старко: «Академічний словник - це словник 1) укладений відповідно до вимог науки; 2) який має статус традиційного / канонічного видання серед подібних; 3) що його підготував і видав відповідний відділ академії наук» [39, с. 176]. Дослідник зауважує, що в разі недотримання першої вимоги, словник навряд чи може претендувати на статус канонічного. Якщо порушено лише другу вимогу, то це свідчить про те, що існує інший подібний словник, якому надають перевагу. Третя вимога $\epsilon$ факультативною, оскільки словник може бути академічним, навіть якщо його уклали не в академії.

\section{4. Проблема дескриптивної та прескриптивної норм у сучасній лінгвістиці}

Розвиток науки про мову у XX ст. частково зумовлений протиставленням дескриптивної та прескриптивної лінгвістики, яке відповідає двом різним поглядам на мову: об'єктивному та нормативному. У нашому дослідженні ми оперуємо термінами «дескриптивний» і «прескриптивний» у широкому розумінні. Дескриптивним вважаємо такий метод лінгвістичного опису, який реалізує об'єктивний, безоцінний погляд на мовні факти, а прескриптивним методом - зорієнтований на створення приписів та рекомендацій щодо вживання мовних одиниць.

Необхідність розрізнення дескриптивного та прескриптивного підходів у сучасній теоретичній лінгвістиці, на думку Г.М. Яворської, не викликає сумнівів, хоча оцінка прескриптивності і сьогодні коливається від цілковитого заперечення і проголошення несумісності ролі лінгвіста й мовного нормалізатора до визнання статусу нормативної лінгвістики й переконання, що саме лінгвіст може бути найкомпетентнішим і найефективнішим мовним нормалізатором [52, с. 17-18].

Б. Фаска дескриптивною називає норму, «абсолютно ідентичну можливостям, які надані системою мови» [цит. за 41, с. 37]. Така норма не вилучає жодного варіанта із суми всіх можливих. Як стверд- 
жує П.О. Селігей, «описувачі» вважають, що норма має грунтуватися винятково на узусі, а мовознавець - лише сторонній спостерігач, споглядальник. Його справа - збирати мовні факти й описувати їх у нейтральний, безоцінний спосіб [36, с. 68]. Дескриптивна норма відображає лексеми, словоформи, й мовні конструкції, які реально вживаються в мові. Вони не завжди відповідають установленим зразкам, адже на них позначаються і стилістичний потенціал, і екстралінгвальні чинники, і постійні внутрішньосистемні пошуки [18, с. 48]. Тобто всі можливості певної мовної системи, які прийняті й репродукуються лінгвосоціумом, становлять дескриптивну норму.

Л.В. Струганець виділяє такі ознаки дескриптивної норми: 1) вона детермінована лише системою мови і іiі внутрішніми закономірностями; 2) вона еволюціонує у процесі зміни й одночасно зі зміною в системі мови; 3) вона не унеможливлює жодних реальних, реалізованих і тих, які реалізуються, перспектив мовної системи, тобто визначається варіантністю [41, с. 37].

Окрім дескриптивної норми мовознавці також виокремлюють прескриптивну норму, яка є ідеальною, але часто недосяжною. За лінгвістичним словником О.О. Селіванової, прескриптивне мовознавство - це «розділ мовознавства, що вивчає проблеми унормування (кодифікації) мовних форм, їхньої оцінки під кутом зору правильності, естетичності, раціональності тощо» [35, с. 487]. Є.А. Карпіловська також наголошує на прескриптивному характері мовної норми, стверджуючи, що вона «радить мовцям, як краще висловити свою думку, які засоби дібрати для кращого взаєморозуміння» [14, с. 44].

У мовознавстві прескриптивний підхід охоплює проблеми стандартизації вимови, синтаксису, коректного стилістичного використання лексичних засобів тощо. На думку Г.В. Гайович, «прескриптивісти пропагують те, що певні групи мовного колективу розглядають як добрий смак. Якщо ці смаки консервативні, прескриптивне мовознавство може нав'язувати суспільству незмінність мови, якщо радикальні - продукувати неологізми» [3, с. 40]. Таким чином, прескриптивний підхід до вивчення мовних явищ містить рекомендації щодо їх ефективного використання, а прескриптивна норма є сукупністю тенденцій відбору і правил використання мовних засобів [3, с. 42]. Стабільність прескриптивної норми залежить від культурно-історичної ситуації, мовної структури та 
особливостей генези її літературної форми [18, с. 48]. Якщо літературна традиція, освіта й соціальний статус такої норми у країні є сприятливими, то вона може бути доволі консервативною.

Специфіка прескриптивного лінгвістичного підходу як принципово позначеного оцінним ставленням до мови розкривається в його протиставленні дескриптивній лінгвістиці, зорієнтованій на безоцінну об'єктивність [3, с. 45]. Як стверджує О.М. Пешковський, лінгвіст виступає у двох ролях: спостерігача-науковця та учасника мовного процесу. При цьому лінгвіст «як учасник мовного процесу, як член цієї мовної спільноти розцінює мовні факти нарівні з усіма іншими освіченими людьми» [30, с. 298]. На думку Г.М. Яворської, із цього випливають два суттєвих моменти, хоча й не сформульовані експліцитно. По-перше, хоча в лінгвіста, на відміну від нефахівця, набагато більше спеціальних знань, система норм і цінностей, якою він послуговується під час оцінювання мовних фактів (тобто в ролі нормативіста), $є$ тією ж самою, що й у звичайного носія мови. По-друге, прескриптивний підхід, принаймні щодо літературної норми, реалізується через погляд на мову зсередини, з точки зору носія мови («учасника мовного процесу, члена мовної спільноти») [52, с. 21].

Аналіз дихотомії «прескрипція - дескрипція» підтверджує, що ці два мовні явища не лише конкурують між собою, але і взаємодоповнюють і взаємодіють одне з одним: дескриптивна лінгвістика робить спостереження й об'єктивний опис певного матеріалу, а прескриптивна лінгвістика на основі цього робить узагальнення й виводить правила [3, с. 42]. Підстав різко протиставляти ці явища або вивищувати одне за рахунок іншого немає. Як стверджує П.О. Селігей, «той, хто принципово не дає мовним явищам оцінок (там, де вони потрібні), схоже, прагне уникнути відповідальності за свою позицію» [36, с. 68]. Водночас дослідник наголошує, що кожен мовознавець має право обирати: чи просто описувати узус, фіксуючи закономірності й тенденції (мова якою вона $\epsilon$ ), чи, крім цього, ще й виробляти рекомендації з метою цей Узус змінити (якою мова має бути).

Натомість Г.М. Яворська констатує, що під час опису літературної норми «дослідникові надзвичайно важко утриматися від оцінних суджень, зберегти об'єктивний погляд на речі, побудувати виклад за принципом sine ira et studio, без гніву та упередження», тому пропо- 
нує два виходи з такої ситуації. Суть першого, на іiї думку, полягає в утриманні від спроби об'єктивно проаналізувати сучасний стан речей, адже описувати результати певних процесів можна лише після того, як вони деякий час «відстояться». Другий вимагає не лише розгляду фактів, а й створення відповідної теоретичної моделі їхньої інтерпретації, для того «щоб за позірною сваволею проглянули певні закономірності» [52, с. 153-154].

Варто відзначити, що співвідношення дескриптивного та прескриптивного підходів до мови будується таким чином, що дескриптивність логічно не вимагає прескриптивності (вона може існувати окремо), натомість прескриптивність обов'язково передбачає процедуру опису - адже для того, щоб сформулювати норму, потрібно уявити той стан речей, який підлягає нормативному регулюванню [3, с. 42]. Як зазначає Т.А. Коць, прескриптивна норма не завжди встигає відбивати тенденції дескриптивної норми, а дескриптивна норма не завжди відповідає ідеальній прескриптивній нормі [17, с. 190-194].

Погоджуємося з Г.М. Яворською, яка грунтовно аналізує поняття дескриптивна та прескриптивна лінгвістика і вважає, що для створення літературних норм важливим є об'єктивний опис мовного матеріалу, який здійснює дескриптивна лінгвістика, та втілення приписів і рекомендацій щодо його використання, що робить прескриптивна лінгвістика [52, с. 299]. Ці принципи реалізуються в нормативному словнику, адже дескриптивний підхід розглядає мову такою, яка вона $\epsilon$ (реєстр словника, джерельна база), а прескриптивний - якою вона має бути (рекомендації щодо вживання мовного матеріалу, що реалізуються через систему обмежувальних ремарок у словнику) [52, с. 24]. Але й реєстр не є об'єктивною даністю: він формується залежно від спеціалізації словника, впливів часу, тиску ідеології, лінгвістичної думки та особистих уподобань укладача (укладачів) словника. Тому введення чи вилучення того чи того слова до реєстру теж є проявом формування прескриптивної норми.

\section{5. Висновки}

Отже, рефлексії над поняттям мовної норми відбувалися досить активно і тривають сьогодні, оскільки функціонування норми пов'язане з категорією оцінки. За час свого існування поняття «норма» 
зазнало істотних змін і уточнень щодо змісту та обсягу. На початку $\mathrm{XX}$ ст. мовознавці наголошували на системному характері норми i трактували ії як складну упорядковану структуру, верхів'я якої займає літературна мова. Цей аспект у розумінні поняття «норма» залишився непорушним до сьогодні. Однак сучасні дослідники визнають подвійну природу норми - як явища системного й суспільного водночас, i тлумачать іï як найстійкіший мовний факт, відібраний у процесі суспільної комунікації, який відповідає системі мови й отримав суспільне схвалення та визнання.

Наслідком визнання мовної норми постає її кодифікація в авторитетних виданнях: граматиках, словниках тощо. Кодифікація має низку ознак: системність, об'єктивність, загальнообов'язковість, наддіалектність, перспективність. Кодифікація 20-30-х рр. ХХ ст., яка стала об'єктом нашої пильної уваги, значно вплинула на подальший розвиток української літературної мови, визначила засади наукового опрацювання ії лексичного складу. У цей період дослідники заперечували стихійні норми, а основну увагу зосередили на системних принципах унормування української літературної мови. Такі принципи залишилися актуальними й у наш час.

Найдостовірнішими фіксаторами змін у лексико-семантичній системі мови й кодифікаторами норм літературної мови є загальномовні лексикографічні праці, оскільки саме в них віддзеркалюються рівень розвитку літературних норм, стан суспільної мовосвідомості етносу в той чи інший період. Загальномовні нормативні словники сприяють підвищенню культури особистості й водночас є засобом цілеспрямованої й науково обгрунтованої мовної політики. Користувачі загальномовних словників підвищують культуру власного мовлення, розвивають мовний смак і чуття слова.

У дослідженні здійснено розмежування дескриптивної та прескриптивної норм за такими критеріями: ставлення до мови (оцінне / безоцінне); опис / відбір мовного матеріалу; наявність / відсутність рекомендацій щодо вживання мовного матеріалу. 3 огляду на це дескриптивною нормою вважаємо систему різнорівневих одиниць, які реально функціонують у мові, а прескриптивною - регульовану за допомогою приписів та рекомендацій, переважно кодифіковану систему мовних одиниць. 


\section{Список літератури:}

1. Бибик С.П. Стильова розмовна норма та розмовна лексика. Культура слова. 2011. № 74. С. 59-65.

2. Вербицкая Л.А. Давайте говорить правильно : учеб. пособие для студентов вузов. Москва : Высшая школа, 2003. 239 с.

3. Гайович Г.В. Прескриптивний підхід до вивчення мовних явищ: зміст, значення, проблеми. Гуманітарна освіта в технічних вищих навчальних закладах. 2012. № 26. С. 39-47.

4. Ганич Д.І., Олійник І.С. Словник лінгвістичних термінів. Київ : Вища школа, 1985. $360 \mathrm{c.}$

5. Гладкий М.Д. Стабілізація української мови. Життя й революиія. 1927. № 4. С. 60-78.

6. Горбачевич К.С. Современная нормативная лексикография. Вестник АН СССР. 1982. № 1. С. 77-86.

7. Горецький П.Й. Методологічні принципи складання загальних двомовних перекладних словників. Лексикографічний бюлетень. 1951. Вип. 1. C. 5-21.

8. Ельмслев Л. Пролегомены к теории языка: пер. с англ. М. : КомКнига, 2006. 248 c.

9. Срмоленко С.Я. Динаміка літературних норм. Najnowsze dzieje języków słowiańskich. Українська мова / Red. nauk. S. Jermolenko. Opole : Un-t Opolski, 1999. S. 221-227.

10. Срмоленко С.Я. Диференційні ознаки літературної мови. Літературна норма і мовна практика: монографія. Київ, 2013. С. 6-20.

11. Срмоленко С.Я. Просторова і часова глибина літературної норми. Літературна норма і мовна практика: монографія. Київ, 2013. С. 65-73.

12. Жовтобрюх М.А., Кулик Б.М. Курс сучасної української літературної мови: підручник для факультетів мови і літератури педагогічних інститутів. Частина I. Видання третє. Київ : Радянська школа, 1965. 423 с.

13. Ицкович В.А. Норма и ее кодификация. Актуальные проблемы культуры речи: сборник статей. Москва : Наука, 1970. С. 9-39.

14. Карпіловська Є.А. Норма в сучасному українському словотворенні: зразок і реальність. Культура слова. 2011. № 74. С. 43-51.

15. Клименко О.С. Сучасна теорія норми і нормалізації і французька прескриптивна лінгвістика. Проблеми семантики, прагматики та когнітивної лінгвістики. 2010. Вип. 18. С. 154-164.

16. Коваль А.П. Слово про слово. Київ : Радянська школа, 1986. 384 с.

17. Коць Т.А. Динаміка граматичної норми. Літературна норма і мовна практика : монографія / За ред. С.Я. Срмоленко. Київ, 2013. С. 137-210.

18. Коць Т.А. Про прескриптивну і дескриптивну норму в граматиці. Культура слова. 2010. № 72. С. 47-55.

19. Кравчук А.М. Мовна норма в польських словниках. Проблеми слов'янознавства. 2008. Вип. 57. С. 161-173.

20. Крысин Л.П. Современная литературная норма и ее кодификация. Русский язык в школе. 2002. № 1. С. 82-87. 
21. Лаптева O.А. Стратификация литературной нормы. Stylistyka. 1994. Вып. 3. С. 154-164.

22. Лингвистический энциклопедический словарь / Главный редактор B.Н. Ярцева. Москва : «Советская энциклопедия», 1990. URL: tapemark.narod.ru/ les/532c.html (дата звернення: 29.10.2019).

23. Матезиус В. О необходимости стабильности литературного языка. Пражский лингвистический кружок. Москва : Наука, 1967. С. 361-386.

24. Мацюк Г.П. Прескриптивне мовознавство в Галичині (перша половина XIX ст.). Львів : Видавничий центр ЛНУ імені Івана Франка, 2001. 373 с.

25. Мельник Т.П. Процеси унормування лексики української мови у 20-30 pp. ХХ століття : автореф. дис. ... канд. філол. наук : спец. 10.02.01 «Українська мова». Київ, 2010.21 с.

26. Муромцева О.Г., Жовтобрюх В.Ф. Культура мови вчителя: курс лекцій для студ. вищ. пед. закл. освіти. Харків : Гриф, 1998. 206 с.

27. Новое в зарубежной лингвистике. Теория литературного языка в работах ученых ЧССР : сборник / Состав. и ред. Н.А. Кондрашов. Вып. 20. Москва : Прогресс, 1988. 320 с.

28. Ожегов С.И. Очередные вопросы культуры речи. Вопросы культуры речи. 1955. Вып. 1. С. 5-34.

29. Паламарчук Л.С. Українська радянська лексикографія: Питання історії, теорії та практики. Київ : «Наукова думка», 1978. 203 с.

30. Пешковский А.М. Объективная и нормативная точка зрения на язык. История языкознания XIX-XX вв. в очерках и извлечениях / В.А. Звегинцев. Т. 2. Москва : Просвещение, 1965. С. 288-299.

31. Пилинський М.М. Мовна норма і стиль. Київ : Наук. думка, 1976. 288 с.

32. Поздрань Ю.В. «Російсько-український словник» за редакцією А. Ю. Кримського та С.О. Єфремова в історико-лінгвістичному контексті / За наук. ред. О.М. Тищенко. Вінниця : ВНТУ, 2018. 292 с.

33. Пражский лингвистический кружок / Под ред. Н.А. Кондрашова. Москва : Наука, 1967. 417 с.

34. Селіванова О.О. Сучасна лінгвістика: напрями та проблеми : підручник. Полтава : Довкілля-К, 2008. 712 с.

35. Селіванова О.О. Сучасна лінгвістика: термінологічна енциклопедія. Полтава : Довкілля-К, 2006. 716 с.

36. Селігей П.О. Нормативний підхід у мовознавстві й мовна критика. Стиль і текст. 2012. Вип. 13. С. 66-72.

37. Семенюк Н.Н. Норма. Общее языкознание. Москва : Просвещение, 1970. С. $524-571$.

38. Семчинський С.В. Загальне мовознавство. Київ : Вища школа, 1988. 328 с.

39. Старко В.Ф. «Російсько-український словник» (1924-1933) та українське академічне словникарство. Украӥнське мовознавство. 2008. Вип. 38. C. $174-180$.

40. Струганець Л.В. Динаміка лексичних норм української літературної мови XX ст. : автореф. дис. ... докт. філол. наук спец. : 10.02 .01 «Українська мова»; К., 2002. 32 с. 
41. Струганець Л.В. Диференційні ознаки норми літературної мови. Культура слова. 2011. № 74. С. 34-43.

42. Сулима М.Ф. Проблема літературної норми в українській мові. Шлях освіти. 1928. № 4. С. 132-141.

43. Сюта Г.М. Художній стиль - складник національної лінгвокультури. Літературна норма і мовна практика: монографія / За ред. С.Я. Срмоленко. Київ, 2013. С. 41-64.

44. Тараненко О.О. Дієслово в контексті сучасних тенденцій до перегляду нормативних засад української літературної мови. Мовознавство. 2006. № 2-3. С. 55-78.

45. Українська мова. Енциклопедія / Редкол.: Русанівський В.М., Тараненко О.О. (співголови), Зяблюк М.П. та ін. 3-є вид., зі змінами і доп. Київ : Вид-во «Укр. енцикл.» ім. М.П. Бажана, 2007. 856 с.

46. Чак Є.Д. Складні випадки українського слововживання. Видання друге, доповнене. Київ : Радянська школа, 1969. 219 с.

47. Черемська О.С. Історичний характер мовної норми. Українська мова y XXI столітті: традиції $i$ новаторство: тези доповідей II Всеукраїнського лінгвістичного форуму молодих учених. Київ, 2012. С. 167-170.

48. Шевельов Ю.В. Покоління двадцятих років в українському мовознавстві. Портрети українських мовознавиів / Ю.В. Шевельов. Київ : Видавничий дім «КМ Академія», 2002. С. 8-30.

49. Шевченко С.П. Спроба кодифікації морфологічних норм укрїнської літературної мови в праці М. Сулими «Дещо про зниклі дієприкметники». Наукові записки НДУ ім. М. Гоголя. Серія : Філологічні науки. 2011. Кн. 1. С. $49-51$.

50. Шмелев Д.Н. Современный русский язык. Лексика. Москва : Просвещение, 1977. 335 с.

51. Щерба Л.В. Языковая система и речевая деятельность. Л. : Наука, $1974.428 \mathrm{c}$.

52. Яворська Г.М. Прескриптивна лінгвістика як дискурс. Мова, культура, влада. Київ : Нац. акад. наук України, Ін-т мовознавства ім. О.О. Потебні, 2000. 288 с.

53. Findra J. Jazyk, reč, človek. Bratislava : Vydavatel'stvo Q 111, 1998. $111 \mathrm{~s}$.

54. Havránek B. Úvodem. Slovo o slovesnost. 1935. № 1. Č. 1. $38 \mathrm{~s}$.

55. Karłowicz J. Przyczynki do projektu wielkiego słownika języka polskiego. Rozprawy $i$ sprawozdania $z$ posiedzeń Wydziatu Filologicznego Akademii Umiejętności. 1876. T. 4. S. XIV-XCIV.

56. Nelson G. Description and Prescription. The Encyclopedia of Language and Linguistics / ed. K. Brown. [2-nd ed.]. Oxford : Elsevier, 2006. V. 3. P. 460-465.

57. Nowy słownik poprawnej polszczyzny / Red. A. Markowski. Warszawa, 1999. $1786 \mathrm{~s}$.

\section{References:}

1. Bybyk S.P. (2011). Stylova rozmovna norma ta rozmovna leksyka [Style spoken norm and spoken vocabylary]. Kultura slova, no. 74, pp. 59-65. 
2. Verbitskaia L.A. (2003). Davaite govorit pravilno: uchebnoe posobie dlia studentov vuzov [Let's say it right: tutorial for university students]. Moscow: Vysshaia shkola.

3. Hayovych H.V. (2012). Preskryptyvnyi pidkhid do vyvchennia movnykh yavyshch: zmist, znachennia, problemy [Prescriptive approach to the sudy of linguistic phenomena: content, meaning, problems]. Humanitarna osvita $v$ tekhnichnykh vyshchykh navchalnykh zakladakh, no. 26, pp. 39-47.

4. Hanych D.I., Oliinyk I.S. (1985). Slovnyk linhvistychnykh terminiv [Dictionary of linguistic terms]. Kyiv: Vyshcha shkola.

5. Hladkyi M.D. (1927). Stabilizaciia ukrainskoi movy [Stabilization of the Ukrainian language]. Zhyttia i revoliuciia, no. 4, pp. 60-78.

6. Gorbachevich K.S. (1982). Sovremennaia normativnaia leksikografiia [Modern normative lexicography]. Vestnik AN SSSR, no. 1, pp. 77-86.

7. Horetskyi P.Y. (1951). Metodolohichni pryntsypy skladannia zahalnykh dvomovnykh perekladnykh slovnykiv [Methodological principles for making common bilingual translation dictionaries.]. Leksykohrafichnyi biuleten, vol. 1, pp. 5-21.

8. Elmslev L. (2006). Prolegomeny $k$ teorii iazyka [Prolegomena to the theory of language: translation from English]. Moscow: KomKniga.

9. Yermolenko S.Ya. (1999). Dynamika literaturnykh norm [Dynamics of literary norms]. Najnowsze dzieje języków stowiańskich. Ukrajinsjka mova [The latest history of Slavic languages. Ukrainian language] / ed. by S.Yermolenko. Opole: University Opolski, pp. 221-227.

10. Yermolenko S.Ya. (2013). Dyferentsiini oznaky literaturnoi movy [Differential features of literary language]. Literaturna norma i movna praktyka: monohrafiia [Literary norm and language practice] / ed. by S.Ya. Yermolenko. Kyiv, pp. 6-20.

11. Yermolenko S.Ya. (2013). Prostorova i chasova hlybyna literaturnoi normy [Spatial and temporal depth of the literary norm]. Literaturna norma $i$ movna praktyka: monohrafiia [Literary norm and language practice] / ed. by S.Ya. Yermolenko. Kyiv, pp. 65-73.

12. Zhovtobriukh M.A., Kulyk B.M. (1965). Kurs suchasnoi ukrainskoi literaturnoi movy: pidruchnyk dlia fakultetiv movy i literatury pedahohichnykh instytutiv [Modern Ukrainian Literary Language Course: A Textbook for the Faculties of Language and Literature of Pedagogical Institutes]. Kyiv: Radianska shkola.

13. Itskovich V.A. (1970). Norma i ee kodifikatsiia [Norm and its codification]. Aktualnye problemy kultury rechi: sbornik statei, pp. 9-39.

14. Karpilovska Ye.A. (2011). Norma v suchasnomu ukrainskomu slovotvorenni: zrazok $\mathrm{i}$ realnist [The norm in the modern Ukrainian word formation: model and reality]. Kultura slova, no. 74, pp. 43-51.

15. Klymenko O.S. (2010). Suchasna teoriia normy i normalizatsii i frantsuzka preskryptyvna linhvistyka [Modern theory of norm and normalization and French prescriptive linguistics]. Problemy semantyky, prahmatyky ta kohnityvnoi linhvistyky, vol. 18, pp. 154-164.

16. Koval A.P. (1986). Slovo pro slovo [Word about word]. Kyiv: Radianska shkola. 
17. Kots T.A. (2013). Dynamika hramatychnoi normy [Dynamics of grammatical norm]. Literaturna norma i movna praktyka: monohrafia [Literary norm and language practice: monograph] / ed. by S.Ya. Yermolenko. Kyiv, pp. 137-210.

18. Kots T.A. (2010). Pro preskryptyvnu i deskryptyvnu normu v hramatytsi [About the prescriptive and descriptive norm in grammar]. Kultura slova, no. 72, pp. 47-55.

19. Kravchuk A.M. (2008). Movna norma v polskykh slovnykakh [The language standard in Polish dictionaries]. Problemy slovianoznavstva, vol. 57, pp. 161-173.

20. Krysin L. (2002). Sovremennaia literaturnaia norma i ee kodifikatsiia [Modern literary norm and its codification]. Russkii iazyk v shkole, no. 1, pp. 82-87.

21. Lapteva O.A. (1994). Stratifikatsiia literaturnoi normy [Stratification of literary norm]. Stilistika, vol. 3, pp. 154-164.

22. Iartseva V.N. (1990). Lingvisticheskii entsiklopedicheskii slovar [Linguistic Encyclopaedia]. Moscow: «Sovetskaia entsiklopediia». Available at: tapemark.narod.ru/les/532c.html (accessed 29 october 2019).

23. Matezius V. (1967). O neobkhodimosti stabilnosti literaturnogo iazyka []. Prazhskii lingvisticheskii kruzhok [About the need of stability of the literary language]. Moscow: Nauka, pp. 361-386.

24. Matsiuk H.P. (2001). Preskryptyvne movoznavstvo $v$ Halychyni (persha polovyna XIKX st.) [Prescriptive Linguistics in Galicia (first half of the 19th century)]. Lviv: Vydavnychyi centr LNU imeni Ivana Franka.

25. Melnyk T.P. (2010). Procesy unormuvannia leksyky ukrainsjkoi movy u 20-30 rr. XX stolittia [The processes of normalization of the Ukrainian language vocabulary in the 20-30's of the XX century] (Avtoreferat dysertatsii kandydata filolohichnykh nauk). Kyiv.

26. Muromtseva O.H., Zhovtobriukh, V.F. (1998). Kultura movy vchytelia: kurs lektsii dlia studentiv vyshchykh pedahohichnykh zakladiv osvity [Teacher's language culture: a course of lectures for students of higher pedagogical education institutions]. Kharkiv: Hryf.

27. Kondrashov N.A. (1988). Novoe v zarubezhnoi lingvistike [The theory of literary language in the works of scientists of Czechoslovakia]. Teoriia literaturnogo iazyka v rabotakh uchenykh ChSSR: sbornik [collection]. Moscow: Progress, vol. 20.

28. Ozhegov S.I. (1955). Ocherednye voprosy kultury rechi [Regular issues of speech culture]. Voprosy kultury rechi, vol. 1, pp. 5-34.

29. Palamarchuk L.S. (1978). Ukrainska radianjka leksykohrafia: Pytannia istorii, teorii ta praktyky [Ukrainian Soviet Lexicography: Issues of History, Theory and Practice]. Kyiv: «Naukova dumka».

30. Peshkovskii A.M. (1965). Obektivnaia i normativnaia tochka zreniia na yazyk [Objective and normative point of view on the language]. Istoriia iazykoznaniia XIX-XXvv. vocherkakh i izvlecheniiakh [History of linguistics of the 19th-20th centuries in essays and extracts] / V.A. Zvegintsev. Moscow: Prosveshchenie, pp. 288-299.

31. Pylynskyi M.M. (1976). Movna norma i styl [Language norm and style]. Kyiv: Naukova dumka. 
32. Pozdran Yu.V. (2018). «Rosiisko-ukrainskij slovnyk» za redaktsiieiu A.Yu. Krymskoho ta S. O. Jefremova vistoryko-linhvistychnomu konteksti [«RussianUkrainian Dictionary» edited by A.Yu. Krymsky and S. Yefremov in HistoricalLinguistic Context] / ed. by O.M. Tyshchenko. Vinnytsia: VNTU.

33. Kondrashov N.A. (1967). Prazhskii lingvisticheskii kruzhok [Prague Linguistic Study Group]. Moscow: Nauka.

34. Selivanova O.O. (2008). Suchasna linhvistyka: napriamy ta problemy: pidruchnyk [Modern linguistics: directions and problems: textbook]. Poltava: Dovkillia-K.

35. Selivanova O.O. (2006). Suchasna linghvistyka: terminolohichna entsyklopediia [Modern linguistics: a terminological encyclopedia]. Poltava: Dovkillia-K.

36. Selihei P.O. (2012). Normatyvnyi pidkhid u movoznavstvi i movna krytyka [The normative approach in linguistics and linguistic criticism]. Styl i tekst, vol. 13, pp. 66-72.

37. Semeniuk N.N. (1970). Norma [Norm]. Obshchee yazykoznanie [General linguistics]. Moscow: Prosveshchenie, pp. 524-571.

38. Semchynskyi S.V. (1988). Zahalne movoznavstvo [General linguistics]. Kyiv: Vyshcha shkola.

39. Starko V.F. (2008). «Rosiisko-ukrainskyi slovnyk» (1924-1933) ta ukrainske akademichne slovnykarstvo [«Russian-Ukrainian Dictionary» (1924-1933) and Ukrainian Academic Dictionary]. Ukrainske movoznavstvo, vol. 38, pp. $174-180$.

40. Struhanets L.V. (2002). Dynamika leksychnykh norm ukrainskoi literaturnoi movy XX st. [Dynamics of lexical norms of the Ukrainian literary language of the twentieth century]. (Avtoreferat dysertatsii doktora filolohichnych nauk). Kyiv.

41. Struhanets L.V. (2011). Dyferentsiini oznaky normy literaturnoi movy [Differential features of the norm of literary language]. Kultura slova, no. 74, pp. 34-43.

42. Sulyma M.F. (1928). Problema literaturnoi normy v ukrainskii movi [The problem of literary norm in the Ukrainian language]. Shliakh osvity, no. 4, pp. 132-141.

43. Siuta H.M. (2013). Khudozhnii styl - skladnyk natsionalnoi linhvokultury [Artistic style is a component of national linguoculture]. Literaturna norma $i$ movna praktyka: monohrafiia [Literary norm and language practice: monograph] / ed. by S.Ya. Yermolenko. Kyiv, pp. 41-64.

44. Taranenko O.O. (2006). Diieslovo v konteksti suchasnykh tendentsii do perehliadu normatyvnykh zasad ukrainskoi literaturnoi movy [Verb in the context of current tendencies to revising the normative foundations of the Ukrainian literary language]. Movoznavstvo, no. 2-3, pp. 55-78.

45. Rusanivskyi V.M., Taranenko O.O., Ziabliuk M.P. ta in. (2007). Ukrainska mova. Entsyklopediia [Ukrainian language. Encyclopedia]. Kyiv: «Ukr. encykl.» im. M.P. Bazhana.

46. Chak Ye.D. (1969). Skladni vypadky ukrainskoho slovovzhyvannia [Difficult cases of Ukrainian usage]. Kyiv: Radianska shkola.

47. Cheremska O.S. (2012). Istorychnyi kharakter movnoi normy [Historical nature of the language norm]. Proceedings of the Ukrainska mova u XXI stolitti: tradytsii i novatorstvo: tezy dopovidei II Vseukrainskoho linhvistychnoho forumu molodykh uchenykh. Kyiv, pp. 167-170. 
48. Shevelov Yu.V. (2002). Pokolinnia dvadtsiatykh rokiv v ukrainskomu movoznavstvi [Generation of twenties in Ukrainian linguistics]. Portrety ukrainskykh movoznavtsiv [Portraits of Ukrainian linguists] / Yu.V. Shevelov. Kyiv: Vydavnychyi dim «KM Akademiia».

49. Shevchenko S.P. (2011). Sproba kodyfikatsii morfolohichnykh norm ukrainskoi literaturnoi movy v pratsi M. Sulymy «Deshcho pro znykli diieprykmetnyky» [An attempt to codify the morphological language in M. Sulima's work "Something about the missing participles"]. Naukovi zapysky NDU im. M. Hoholia. Seriia : Filolohichni nauky, vol. 1, pp. 49-51.

50. Shmelev D.N. (1977). Sovremennyi russkii iazyk. Leksika [Modern Russian language. Vocabulary]. Moscow: Prosveshchenie.

51. Shcherba L.V. (1974). Yazykovaya sistema $i$ rechevaya deyatelnost [Language system and speech activity]. L.: Nauka.

52. Javorska H.M.(1998). Preskryptyvna linhvistyka yak dyskurs. Mova, kultura, vlada [Prescriptive linguistics as a discourse. Language, culture, power]. Kyiv: Natsionalna akademiia nauk Ukrainy, Instytutt movoznavstva im. O.O. Potebni.

53. Findra J. (1998). Jazyk, reč, človek [Language, speech, man]. Bratislava: Q 111.

54. Havránek B. (1935). Úvodem [Introduction]. Slovo o slovesnost, no. 1, pp. 1-38.

55. Karłowicz J. (1876). Przyczynki do projektu wielkiego słownika języka polskiego [Contribution to the project of the great dictionary of the Polish language]. Rozprawy i sprawozdania z posiedzeń Wydziału Filologicznego Akademii Umiejętności, vol. 4, pp. XIV-XCIV.

56. Nelson G. (2006). Description and Prescription. The Encyclopedia of Language and Linguistics / ed. K. Brown. Oxford: Elsevier, pp. 460-465.

57. Markowski A. (1999). Nowy stownik poprawnej polszczyzny [New dictionary of the correct Polish]. Warszawa. 